\title{
Does Public Debt Moderate the Effect of Inflation Rate on Securities Market Returns in Kenya?
}

\author{
David J. Kapchanga ${ }^{1^{*}}$, Poti A. Owili ${ }^{2}$, Samuel O. Onyuma ${ }^{3}$ \\ ${ }^{1}$ Laikipia University, School of Business, \\ P. O. Box 1100, Nyahururu 20300, Kenya dkapchanga@ gmail.com \\ ${ }^{2}$ Laikipia University, Department of Mathematics, \\ P. O. Box 1100, Nyahururu 20300, Kenya abajapoti@gmail.com \\ ${ }^{3}$ Laikipia University, School of Business, \\ P. O. Box 1100, Nyahururu 20300, Kenya onyumadoc@gmail.com
}

\begin{abstract}
:
While in the last one decade, Kenya has witnessed increasing levels of public borrowing, both domestic and foreign, economic growth has slowed down and the performance of the securities market has been subdued with falling stock prices. This has prompted stock investors to review and/or realign their investment portfolios. While the inflation rate has been drastically fluctuating, public debt - which is strongly inflationary - has had an exponential increase of about 461 percent between 2008 and 2018 . Although Kenya's level of public debt is approaching unsustainable levels, massive borrowing still continues. Using secondary monthly data obtained from government and securities market databases, this paper analyzed whether public debt moderates the relationship between inflation rate and securities market returns at the Nairobi Securities Exchange. Time series multiple linear regression results show that whereas inflation rate has a statistically significant negative effect on securities market returns, public debt had an insignificant negative effect on securities market returns. More importantly, public debt does not statistically significantly affect the relationship between inflation rate and the securities market in Kenya. Putting in place strategies aimed at reducing inflation as well as public debt can however have the effect of improving securities market performance.
\end{abstract}

Keywords: public debt, market returns, inflation rate, Nairobi Securities Exchange, moderating effect.

\section{Introduction}

Securities markets play an important function of financial intermediation in an economy, furnishing investors with long-term capital and acting as alternative investment channels for surplus funds [1], [2]. They also spur economic growth through mobilization of foreign and domestic investments and avail low cost capital to growth-oriented firms that mitigate reliance on interest rate-sensitive bank finance [3]. In addition, they offer an avenue for liquidation of investments for venture capitalists who want to exit their start-up ventures [4].

The performance of the securities market can be measured using securities market indices, which gauge stock-price adjustments and are the presumed reasonable representatives of the securities market performance as a whole [5]. The indices effectively summarize price movements and convey a clear picture of value movements and market performance
[6].

Securities market indices are then used to compute securities market returns which are the gains or losses of the weighted overall theoretical securities market portfolio, which includes all market securities [7]. The returns benchmark the appraisal of the performance of an individual investor's portfolio, which is a combination of selected market securities. Comparison of the securities market returns with the individual investor's portfolio's returns can show whether the investor is making gains or losses on their investment [8].

In Kenya, the NSE 20 Share Index is the major securities market index used to convey a clear picture of securities' value movements and market performance. It is a narrow-based population index and an equal-weighted geometric mean of a nonrandom sample of twenty large and most active stocks representing all of the NSE segments that represent different Kenyan industries. 
Between March 2008 and March 2018, the NSE 20 Share Index's performance steadily declined, resulting in negative returns where investors lost wealth worth billions, as prices of most securities sharply dwindled. In addition, other indicators of performance, such as volume of shares traded, equity turnover, subscription rates for IPOs and right issues as well as investor participation at the NSE substantially declined, prompting investors to move to other securities markets in search of higher returns [9], [10].

Meanwhile, inflation rate, one of the macroeconomic factors that adversely affects securities market returns by depressing securities prices as a result of investors undervaluing equities in inflationary environments, has been drastically fluctuating between $19.72 \%$ and $3.18 \%$ in the same period [11].

Public debt, which is strongly inflationary [12] especially in developing countries [13] has also had an exponential increase of 461 percent from March 2008 to March 2018 [14]. Despite several warnings from the World Bank that Kenya should work towards reducing its debt levels, which have been approaching unsustainable levels [15], the massive borrowing continues unabated.

This paper, therefore, sought to investigate whether public debt does moderate the relationship between inflation and securities market returns at the Nairobi Securities Exchange. The paper is structured as follows: Section 2 presents a review of literature; Section 3 describes the method employed; Section 4 presents and discusses findings; and Section 5 finally presents the conclusions and outlines some recommendations for policy considerations.

\section{Review of Literature}

Past studies have examined the relationship between inflation rate and securities market returns, public debt and securities market returns, and public debt and inflation rate. These studies have had mixed findings as discussed below.

\subsection{Inflation Rate and Securities Market Returns}

The effect of inflation on securities market returns depends on whether the economy is facing unexpected or expected inflation. The relationship between expected inflation and securities returns will be positive or otherwise depending on the prevailing monetary policy and firms' ability to hedge against future risks [16].

However, unexpected inflation, according to [17], correlates with securities returns more negatively, especially during economic contractions because of the perception that unexpected inflation contains new information that increases stock price volatility.
Past studies on inflation rate's effect on the performance of securities markets have yielded mixed findings. Contrary to Fisher hypothesis [18], negative effects of inflation rate on securities returns were found in the Czech Republic, Bangladesh, Sweden, Nigeria, Botswana and Brazil [19] - [25]. In contrast, there was a positive effect of inflation on securities returns in Ghana, China, India and the European Union [26] - [28].

In Kenya, some studies found that inflation rate had a positive and significant bearing on securities returns [29] - [31], with [32] reporting a negative short-run co-integrating relationship between inflation and securities market performance. Other studies found that inflation rate negatively influenced returns [33] - [38].

\subsection{Public Debt and Securities Market Returns}

Although literature on the effect of public debt on securities market returns is still lean, [28] found that public debt had a positive effect on securities market returns in the European Union. However, this effect was insignificant in developed European Union nations and significant in emerging European Union nations.

Other studies, [39] and [40], also found that public debt's effect on the securities market was insignificant in Nigeria and Kenya respectively, although the effect was negative in Kenya [40]. Assessment of the impact of public debt on Nigeria's securities market [41] found that it had a significant and positive influence on stock prices.

\subsection{Public Debt and Inflation Rate}

The Central Bank of Kenya (CBK) uses monetary policy to stabilize the country's inflation, through actions aimed at controlling the level of money supply in the country. By regulating interest rates, the CBK either introduces or pulls back the liquidity in the country. Excess money in circulation often stimulates depreciation of the Kenyan Shilling, which triggers a high inflation rate that slows down economic growth. One of the CBK's monetary policy actions is selling government securities. This, coupled with international borrowing by the Treasury to finance the national budget deficit, increases public debt [42].

Several studies have examined the effect of public debt on inflation. According to [13] public debt had a significantly positive effect on inflation rate in developing countries. According to [43], in their non-Ricardian theoretical framework, higher levels of public debt are inflationary. Several other studies also support this view that higher public debt increases the rate of inflation, especially in developing countries [44], [45]. Another study [46] suggested that the optimal public debt should be 
pegged on the interaction between inflation rate and changes in government borrowing. Since the above literature confirms that public debt influences inflation rates, and inflation rates influence securities market returns, this study sought to determine if there exists any moderating effect of public debt on the effect of inflation rate on securities market returns.

\section{Research Methodology}

\subsection{Data and Data Collection}

The study employed a descriptive research design which was suitable for fitting a multiple linear regression model to describe the relationship between the dependent, independent and moderating variables. There were 67 firms listed at the Nairobi Securities Exchange during the study period. The NSE 20 Share Index samples the top 20 best performing companies based on trading activity, volume of shares traded, equity turnover, and superior profitability and dividend record. Using a data collection sheet, secondary data was collected on monthly NSE 20 Share Index values from February 2008 to March 2018 as reported by the Nairobi Securities Exchange totaling to 122 monthly observations.

\subsection{Model Specification and Data Analysis}

The securities market returns were computed from the securities market index data using equation (1).

$R t n_{t}=\left(\frac{N S E 20_{t}-N S E 20_{t-1}}{N S E 20_{t-1}}\right) * 100$

Where,

$R_{t} n_{t} \quad=$ Securities market returns at time $\mathrm{t}(\%)$ $N S E 20_{t}=$ value of NSE 20 Share Index at time $\mathrm{t}$ $N S E 20_{t-1}=$ NSE 20 Share Index at time $\mathrm{t}-1$

A total of 122 monthly observations for both inflation rate and public debt, from February 2008 to March 2018, were collected from the Central Bank of Kenya. The descriptive statistics of the raw data are shown in Table 1.

Table 1: Summary Statistics of Raw Data

\begin{tabular}{|c|c|c|c|c|}
\hline Variable & $\begin{array}{c}\text { Securities } \\
\text { market } \\
\text { returns } \\
(\boldsymbol{\%})\end{array}$ & $\begin{array}{c}\text { Inflation } \\
\text { rate } \\
\mathbf{( \% )}\end{array}$ & $\begin{array}{c}\text { Public } \\
\text { debt } \\
\mathbf{( K S h} \\
\text { Million) }\end{array}$ \\
\hline Mean & -0.09897 & 8.516446 & 2207876 \\
\hline Variance & 20.94987 & 21.71366 & $1.31 \mathrm{E}+12$ \\
\hline Std. dev. & 4.577103 & 4.659792 & 1146266 \\
\hline Skew & -0.67511 & 1.109019 & 0.785935 \\
\hline
\end{tabular}

\begin{tabular}{|c|c|c|c|c|}
\hline Kurt & 4.60529 & 2.989097 & 2.456262 \\
\hline Min & -17.9068 & 3.18 & 860957.1 \\
\hline Max & 9.334385 & 19.72 & 4901288 \\
\hline Obs. & 122 & 122 & 122 \\
\hline
\end{tabular}

It is evident from the summary statistics in Table 1 that all the three variables had quite high variances, which are a source of heterogeneous regression residuals [47]. Further, it can be observed that inflation rate and public debt were rightskewed, implying that these variables had a high probability of being less than their means and that deviation from the mean was more likely to be positive. It is also evident that NSE 20 return was negatively skewed, implying that securities market returns had high chances being above average, but more likely to negatively deviate from the mean [48].

To test the linkage between the variables, it was necessary to transform them into forms that were suitable for time series multiple linear regression analysis [49]. First, because of the non-linear nature of the relationship between the variables, the raw data were log-transformed to enable modelling of linear parametric relationships from the non-linear variables. This retained non-linear effective relationship between the dependent and the independent and moderating variables, while still preserving a linear model; hence facilitating comparison through elasticity [47], [20]. As suggested by [50] and [47], the log-transformation also stabilized the variance and reduced positive skewness.

Further, because logarithms of negative numbers is not defined [47], a constant was added to the NSE 20 Share Index returns such that the minimum return was exactly one, as suggested by a recent study on the effect of minimum values on logarithmic transformation of data with negative values [51].

Since multiple linear regression analysis of time series data presumes that all the variables are stationary and not perfectly correlated [47], the variables were tested for stationarity and multicollinearity using the augmented Dickey-Fuller unit root test and Pearson's pairwise correlation matrix respectively before regression analysis. The non-stationary variables were detrended and differenced to eliminate spurious regression [52].

After transformation of the variables, 121 monthly observations from March 2008 to March 2018 were used to fit a multiple linear regression model (with robust standard errors that mitigated the effects of heteroscedasticity) based on a modified Arbitrage Pricing Theoretical model [21]. The study adopted 
the economic model in equation (2), which expressed securities market returns (Rtn) as a function of inflation rate $(I N F)$ given public debt $(P D)$.

$$
\text { Rtn }=f(I N F / P D)
$$

The two econometric models presented in equations (3) and (4) were the economic model's functional form that was used to analyze the data.

$$
\begin{gathered}
\operatorname{LnRtn}_{t}=\alpha_{1}+\beta_{1} \operatorname{LnINF}_{t}+\beta_{2} D d t \operatorname{LnP} D_{t}+\varepsilon_{t} \\
\operatorname{LnRtn}_{t}=\alpha_{1}+\beta_{1} \operatorname{LnINF}_{t}+\emptyset_{2} D d t \operatorname{LnP} D_{i}+ \\
\emptyset_{3} D d t \operatorname{Ln} P D_{i} \operatorname{LnINF}_{t}+\varepsilon_{t}
\end{gathered}
$$

Where,

$\operatorname{LnRtn}_{t}=$ Natural logarithm of securities market returns at time $\mathrm{t}$.

$\operatorname{LnINF}_{t}=$ Natural logarithm of inflation rate at time t.

$D d t \operatorname{LnP} D_{t}=$ First difference of detrended natural logarithm of public debt at time $t$.

$D d t \operatorname{Ln} P D_{i}=$ meaningful values of $\operatorname{Ddt} \operatorname{Ln} P D_{t}$ such as the mean and one standard deviation above and below the mean.

$\beta_{i} / \emptyset_{i}=$ sensitivity of market returns to changes in the $i^{\text {th }}$ variable, $i=$ inflation rate, public debt or their interaction.

$\varepsilon_{t}=$ error term with mean $=0$, variance $=\sigma^{2}$.

Equation (3) was used to determine the main effects of both inflation rate and public debt on securities market returns, while equation (4) was used to determine the moderating effect of public debt on inflation rate's influence on the performance of the securities market, as captured by the interaction term $D d t L n P D_{i} L n I N F_{t}$. The interaction effects were measured by assessing the increment of the R-squared yielded by adding the interaction term. That is, testing whether the R-squared of equation (4) was larger than the R-squared of equation (3).

The moderating effect was further tested by rewriting equation (4) to show simple quadratic functions at selected levels of public debt, corresponding to simple slopes of equation (4), as expressed in equation (5).

$$
\operatorname{LnRtn}_{t}=c_{i}+\gamma_{i} \operatorname{LnINF}_{t}+\epsilon_{t} \quad\{i, 1 \leq i \leq 3
$$

Where,

$c_{i}=\alpha_{1}+\emptyset_{2} D d t \operatorname{Ln} P D_{i}$

$\gamma_{i}=\beta_{1}+\emptyset_{3} D d t \operatorname{Ln} P D_{i}$

$1=$ one standard deviation below mean public debt

$2=$ the mean public debt

$3=$ one standard deviation above mean public debt

The simple quadratic functions indicated by equation (5) were derived from substituting the selected values of public debt (1,2 and 3 above) in the equation (5). The equations yielded were tested graphically for predictive margins $\left\{\beta_{1}+\right.$ $\emptyset_{3} D d t L n P D_{i}$ of equation (4) $\}$ of inflation rate given public debt, and the average marginal effects $\left\{\alpha_{1}+\emptyset_{2} D d t L n P D_{i}\right.$ of equation (4) $\}$ of public debt on the effect of inflation rate on securities market returns.

The study's objectives were achieved by testing the null hypotheses, that inflation rate and public debt did not have statistically significant effects on securities market returns, and that public debt did not statistically significantly moderate the effect of inflation rate on securities market returns, at the 95 percent confidence interval. The study failed to reject the null hypotheses at p-values greater than the 0.05 significance level and made appropriate conclusions. Further, the beta coefficients and their signs were reported and used to evaluate the magnitude and direction of the effect of the variables on securities market returns. R-squared values of the unmoderated and the moderated regression equations were also compared and predictive margins used to investigate the moderating effect of public debt. Data was analyzed using Stata version 13 software.

\section{Results and Discussion}

\subsection{Descriptive Statistics for Log-Transformed data}

Table 2 presents the summary of descriptive statistics for the log-transformed variables.

Table 2: Summary Statistics Log-Transformed Data

\begin{tabular}{|c|c|c|c|}
\hline Variable & $\begin{array}{c}\text { Ln } \\
\text { Securities } \\
\text { market } \\
\text { returns }\end{array}$ & $\begin{array}{c}\text { Ln } \\
\text { Inflation } \\
\text { rate }\end{array}$ & $\begin{array}{c}\text { Ln Public } \\
\text { debt }\end{array}$ \\
\hline Mean & 2.88692 & 2.011818 & 14.47801 \\
\hline Variance & 0.14285 & 0.250092 & 0.260687 \\
\hline Std. dev. & 0.37795 & 0.500092 & 0.510575 \\
\hline Skew & -4.40995 & 0.415474 & 0.159211 \\
\hline Kurt & 31.8467 & 2.304427 & 1.888707 \\
\hline Min & 0 & 1.156881 & 13.6658 \\
\hline Max & 3.34078 & 2.981633 & 15.40501 \\
\hline Obs. & 121 & 121 & 121 \\
\hline
\end{tabular}

Note: Ln = Natural logarithm

It is evident from the summary statistics in Table 
2 that the log-transformation substantially minimized the variances and the right tails of the distribution of the variables' data.

\subsection{Stationarity and Multicollinearity}

\subsubsection{Stationarity Test}

Stationary data is desirable in the regression of time series to eliminate the problem of spurious regression, where variables without a meaningful relation might seem related [53]. A stationary time series is an array of stochastic data points at successive, equal time points, with constant variance and constant mean over time [47]. Based on the processes required to transform a time series to make it stationary, the two types of stationarity are: the difference stationary process (stochastic trend) where taking differences of consecutive observations achieves stationarity; and the trend stationary process (deterministic trend) where detrending achieves stationarity [50].

Noting that a time series might have both stochastic and deterministic trends [47], the study used time series graphs to determine the existence of trend stationarity. Variables with a deterministic trend were detrended by first regressing them on time, subtracting the trend, and using the residuals as the new data for those variables, as suggested by [47] and [53]. Then, the Augmented Dickey-Fuller unit root test was used to investigate the variables for the presence of difference stationary processes, against the null hypothesis that a time series was non-stationary, because it had a unit root. Rejection of the null hypothesis meant that the time series was stationary [47]. Otherwise, the variable was repeatedly differenced and re-tested until it became stationary.

The time series plots for the log-transformed variables that were used to investigate the presence of trend-stationarity are presented in Figure 1, Figure 2, Figure 3 and Figure 4.

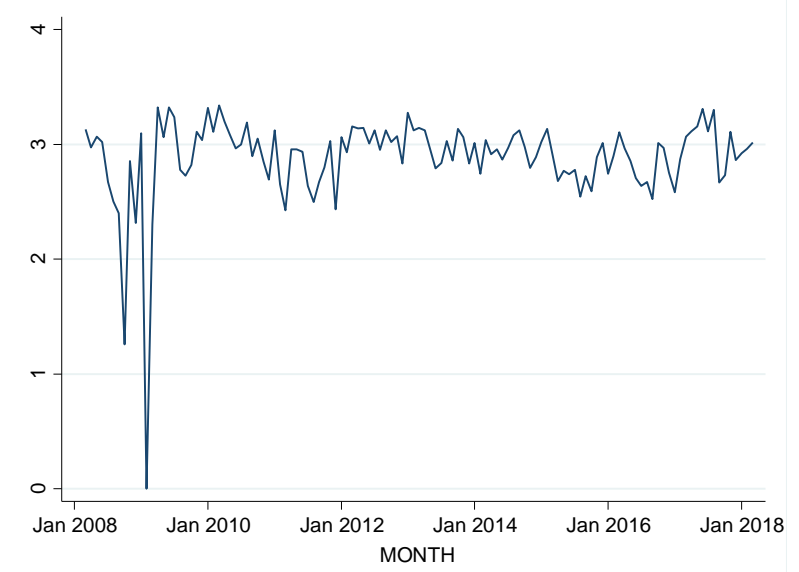

Figure 1: Time series plot - natural log of securities market returns
It is evident from Figure 1 that securities market returns had constant stochastic variations. The time series graph for the natural logarithm of inflation rate is presented in Figure 2.

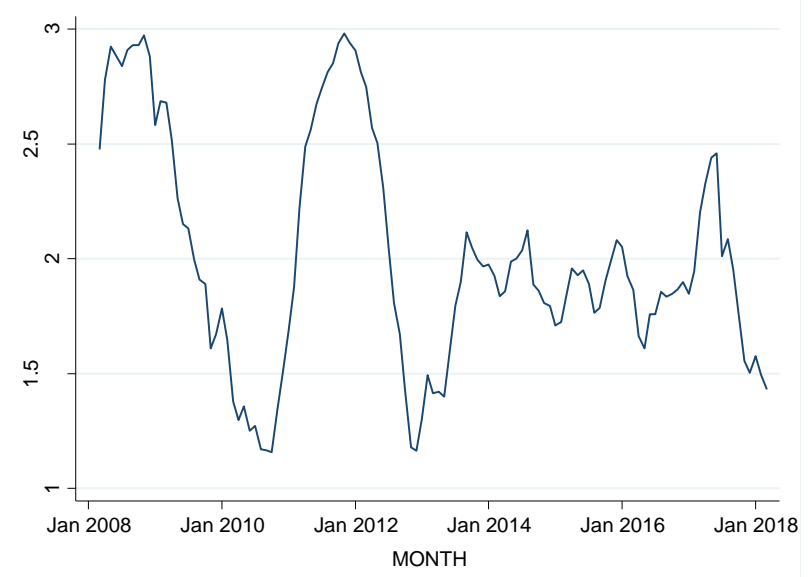

Figure 2. Time series plot - natural log of inflation rate

It is evident from Figure 2 that inflation rate had stochastic variations which appeared constant over time. The time series graph for the natural logarithm of public debt is presented in Figure 3.

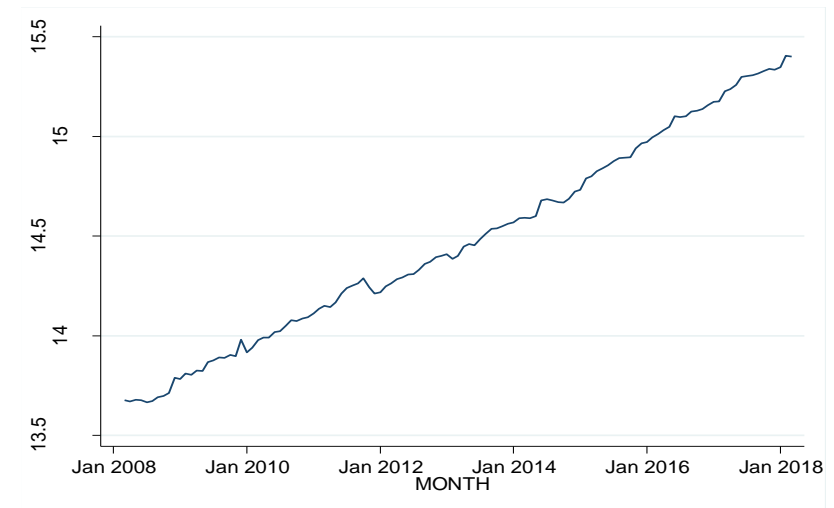

Figure 3. Time series plot - natural log of public debt

It is evident from Figure 3 that public debt had stochastic variations which appeared to have a deterministic trend. Hence, the natural logarithm of public debt was detrended. The time series graph for the detrended natural logarithm of public debt is presented in Figure 4. 


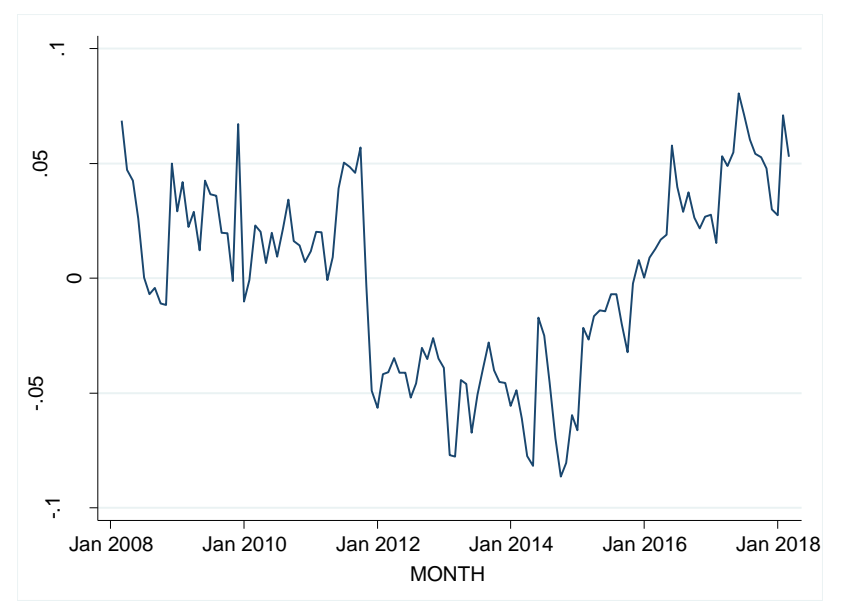

Figure 4. Time series plot - detrended natural log of public debt

It is evident from Figure 4 that public debt had stochastic variations which appeared to have either seasonal or cyclic trends. According to [54], if the data of a seemingly seasonal trend is found to be non-stationary, then differencing can reduce the seasonality. The natural logarithms of securities market returns and inflation rate, and the detrended natural logarithm of public debt were then tested for difference-stationarity using the Augmented DickeyFuller (ADF) unit root test, with lags selected by Akaike Information Criterion and presented in Table 3.

Table 3: Lag-Selection - Akaike Selection Criteria

\begin{tabular}{lrr}
\hline Variable & $\begin{array}{c}\text { AIC } \\
\text { (Optimum) }\end{array}$ & Lag \\
\hline Ln securities market return & 0.713551 & 4 \\
Ln inflation rate & -1.40552 & 5 \\
Detrended Ln public debt & -4.99571 & 2 \\
FD of detrended Ln public & -4.97247 & 5
\end{tabular}

debt

Note: $F D=$ First Difference, Ln $=$ Natural Logarithm

The ADF unit root test was run for each variable with the trend and intercept terms. If, from the results of the ADF unit root test, both the MacKinnon approximate value of $\mathrm{Z}(\mathrm{t})$ and the trend term were found to be insignificant at the 95 percent confidence interval, the ADF unit root test was repeated without the trend term. A variable was said to have a unit root when the MacKinnon approximate at the 95 percent confidence interval was insignificant and the trend or intercept terms were significant. Otherwise, that variable was non- stationary. Table 4 presents the results of the unit root test.

Table 4: Augmented Dickey-Fuller Unit Root Test

\begin{tabular}{lcccr}
\hline \multirow{2}{*}{ Variable } & \multicolumn{2}{c}{$\begin{array}{c}\text { Trend and } \\
\text { Intercept }\end{array}$} & \multicolumn{2}{c}{ Intercept } \\
\cline { 2 - 5 } & $\begin{array}{c}\text { MacKin } \\
\text { non } \\
\text { approx. } \\
\mathbf{Z}(\mathbf{t})\end{array}$ & $\begin{array}{c}\mathbf{p}|\mathbf{t}| \\
\text { for } \\
\text { trend }\end{array}$ & $\begin{array}{c}\text { MacKin } \\
\text { non } \\
\text { approx. } \\
\mathbf{Z}(\mathbf{t})\end{array}$ & $\begin{array}{c}\mathbf{p}>|\mathbf{t}| \\
\text { for } \\
\text { trend }\end{array}$ \\
\hline LnRtn & $* 0.0279$ & 0.274 & - & - \\
LnINF & $* 0.0098$ & 0.284 & - & - \\
dtLnPD & 0.4585 & 0.251 & 0.1618 & 0.909 \\
DdtLnPD & $* 0.0000$ & 0.224 & & \\
\hline
\end{tabular}

Note: $*$ significant at 95 percent confidence interval.

It is evident from the results in Table 4 that the MacKinnon approximate $\mathrm{p}$-value for $\mathrm{Z}$ (t) was significant for securities market returns and inflation rate at the 95 percent confidence interval ( $p=$ 0.0279 and $p=0.0098$ respectively). Hence, the study rejected the null hypotheses and concluded that these variables were stationary at level. It was also evident from the table that the $\mathrm{p}$-value for detrended public debt $(p=0.4585)$ was insignificant at the 95 percent confidence interval, pointing to a possibility of the existence of a unit root. However, since the estimated trend of interest rate was also insignificant $(p=0.251)$, the ADF unit root test was repeated without the trend. The obtained MacKinnon approximate $\mathrm{p}$-values for $\mathrm{Z}(\mathrm{t})$ and the p-value of the intercept were also insignificant at the 95 percent confidence interval ( $p=0.1618$ and $p=0.909$ ). But since the time series plot appeared to have some cyclic/seasonal component, the detrended logarithm of public debt was differenced and retested for differencestationarity, as suggested by [54].

It is evident from Table 4 that the MacKinnon approximate $\mathrm{p}$-value for $\mathrm{Z}(\mathrm{t})$ of the first difference of public debt was significant at the 95 percent confidence interval $(p=0.0000)$. Hence, the study concluded that the first difference of public debt was stationary. Indeed, this was corroborated by the constant variance observed in the time series graph in Figure 5. 


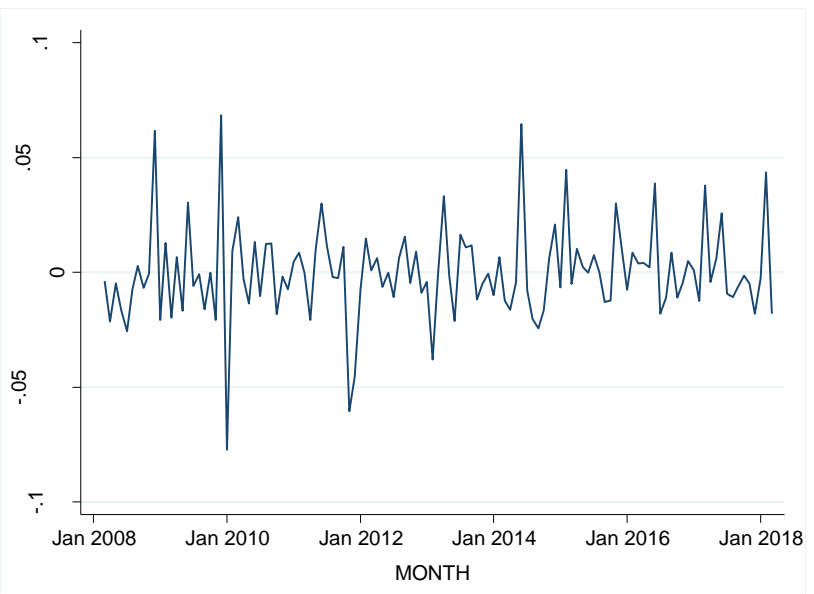

Figure 5. Time series plot - first difference of detrended natural log of public debt

Thus, the study used the natural logarithm of securities market returns as the dependent variable, and the natural logarithm of inflation rate as the independent variable. The first difference of detrended public debt was used as the moderating variable.

\subsubsection{Multicollinearity Test}

One of the assumptions of multiple linear regression modeling is that the independent variables do not have perfect linear relationships [55]. Therefore, multicollinearity tests were conducted to find out whether the independent variables had high linear relationships that would have made it difficult to accurately estimate the coefficients, were they to be included in the regression model together [47].

In multiple linear regression, multicollinearity occurs when one or more independent variables have high linear correlations, making it possible to accurately predict one variable from the other [56]. High multicollinearity may lead to rejection of hypotheses that would otherwise be accepted, due to large standard errors that lead to high p-values and wider confidence intervals [57], [53]. The Pearson's pairwise correlation matrix was used to investigate collinearity of the variables.

The Pearson's pairwise correlation matrix measures the strength of the relationship between the independent variables using coefficients of correlation $(r)$ and the significance of that correlation at a certain confidence interval [65]. A negative coefficient would denote an inverse relationship between two variables, while $r$ of $0.1<|r|<0.3$ would show a small correlation, $0.3<|r|<0.5$ a moderate correlation, and $|r|>0.5$ a strong correlation [58]. Table 5 presents the Pearson's correlation matrix at the 95 percent confidence interval.
Table 5: Pearson's Pairwise Correlation Matrix

\begin{tabular}{|l|c|c|}
\hline & $\begin{array}{c}\text { Ln Inflation } \\
\text { rate }\end{array}$ & $\begin{array}{c}\text { Ln Public } \\
\text { debt }\end{array}$ \\
\hline Ln Inflation rate & 1.0000 & \\
\hline Ln Public debt & -0.0729 & 1.0000 \\
\hline
\end{tabular}

Note: $*$ significant at $95 \%$ Confidence interval; $p$ value in parentheses.

It is evident from the coefficients in Table 5Error! Reference source not found. that inflation rate and public debt had very small and insignificant negative correlation $(r=0.0729, p=0.4266)$ that was not likely to adversely influence the study's regression coefficients.

\subsection{Regression Estimates (Robust Standard Errors)}

\subsubsection{Main Effects of Inflation Rate and Public Debt on Securities Market Returns}

To mitigate the effects of heteroscedasticity, a multiple linear regression with robust standard errors was run with the model in equation (3). Table 6 presents the regression estimates obtained.

Table 6: Regression Estimates (Robust Errors)

\begin{tabular}{|l|l|l|l|l|l|}
\hline LnRtn & Coef. & $\mathrm{t}$ & $\mathrm{P}>|\mathrm{t}|$ & \multicolumn{3}{|c|}{$\begin{array}{l}\text { [95\% Conf. } \\
\text { Interval] }\end{array}$} \\
\hline $\begin{array}{l}\text { Inflation } \\
\text { rate }\end{array}$ & -0.222 & -2.49 & $0.014 *$ & -0.40 & -0.05 \\
\hline $\begin{array}{l}\text { Public } \\
\text { debt }\end{array}$ & -1.231 & -0.91 & 0.366 & -3.92 & 1.45 \\
\hline cons & 3.335 & 21.59 & $0.000^{*}$ & 3.03 & 3.64 \\
\hline $\mathrm{N}$ & & 121 & & & \\
\hline $\mathrm{R}-$ squared & 0.088 & & & \\
\hline $\mathrm{F}[2,118]$ & & 3.12 & & & \\
\hline Prob $>\mathrm{F}$ & 0.047 & & & \\
\hline rmse & & 0.363 & & & \\
\hline
\end{tabular}

$*$ = significant at $95 \%$ Confidence Interval

Using the regression coefficients in Table 6, this paper predicted securities market returns with equation (6).

LnRtn $=3.335-0.222 \operatorname{LnINF}-1.231$ DdtLnPD

It is evident from Table 6 that the two-predictor model accounted for 9 percent of the variation of securities market return, and this effect was significant $(\mathrm{F}(2,118)=3.12$, Prob $>F=0.0479$ and $\mathrm{R}$-squared $=0.0884)$. It is also evident that inflation rate was a significant predictor of securities market returns $(p=0.014)$ while public debt had an insignificant effect on securities market returns $(p=0.366)$. Furthermore, it is evident from Table 6 that both inflation rate and public debt negatively 
influenced securities market returns with the returns declining at an average of about 0.222 percent and 1.231 percent for each percentage increase in inflation rate and public debt respectively, though the influence of public debt on the returns was not significant.

\subsubsection{Moderation Effect of Public Debt on the Effect of Inflation Rate on Securities Market Returns}

Moderation modifies the strength and/or direction of the effect of an independent variable on the dependent variable [59] - [61]. To test the null hypothesis that public debt did not moderate the effect of inflation rate on security market returns, a moderated multiple linear regression was run with the model in equation (4) and the results presented in Table 7. The regression estimates obtained were then compared with those in Table 6.

Table 7: Moderated Regression Estimates (Robust Errors)

\begin{tabular}{|l|c|l|l|l|l|}
\hline LnRtn & Coef. & $\mathbf{t}$ & $\mathbf{P}>|\mathbf{t}|$ & \multicolumn{2}{|l|}{$\begin{array}{l}\text { [95\% } \\
\text { Conf. } \\
\text { Interval }]\end{array}$} \\
\hline $\begin{array}{l}\text { Inflation } \\
\text { rate }\end{array}$ & -0.229 & -2.48 & $0.014^{*}$ & -0.41 & -0.05 \\
\hline $\begin{array}{l}\text { Public } \\
\text { debt }\end{array}$ & 4.313 & 0.87 & 0.386 & -5.51 & 14.1 \\
\hline Int. & -2.667 & -0.99 & 0.326 & -8.02 & 2.69 \\
\hline cons & 3.345 & 21.1 & $0.000^{*}$ & 3.03 & 3.66 \\
\hline N & & 121 & & & \\
\hline R-squared & \multicolumn{2}{|l|}{0.0943} & & \\
\hline Prob > F & \multicolumn{3}{|l|}{0.1058} & & \\
\hline rmse & \multicolumn{3}{|l|}{0.3643} & & \\
\hline
\end{tabular}

$*=$ significant at $95 \%$ Confidence Interval, Int. $=$ interaction between public debt and inflation rate.

It is evident from Table 7 that the moderation model accounted for 9 percent of the variation of securities market returns. However, this effect was insignificant $(\mathrm{F}(2,118)=2.09$, Prob $>\mathrm{F}=0.1058$ and R-squared $=0.0943$ ). It is also evident that inflation rate was a significant predictor of securities market returns $(p=0.014)$ while public debt and the interaction between inflation rate and public debt (Int.) had an insignificant effect on securities market returns ( $p=0.386$ and $p=0.326$ respectively).

Furthermore, while inflation rate negatively influenced securities market returns, public debt positively affected the returns. In addition, the interaction between inflation rate and public debt also negatively influenced securities market returns. On average, for a percentage increase in inflation rate and the interaction between inflation rate and public debt, securities market returns declined by about 0.229 percent and 2.667 percent respectively. In contrast, securities market returns increased by about 4.313 percent for each percent increase in public debt.

\subsection{Hypotheses Testing and Discussion}

\subsubsection{Effect of Inflation Rate on Securities Market Returns}

Table 8 presents the results of the determination of the effect of inflation rate on securities market returns against the null hypothesis that inflation rate does not statistically significantly affect securities market returns at the Nairobi Securities Exchange, that is, $H_{0}: \beta_{1}=0$.

Table 8: Regression Estimates - Inflation Rate

\begin{tabular}{|l|c|c|c|c|}
\hline Variable & \multicolumn{1}{|c|}{$\boldsymbol{\beta}_{\mathbf{1}}$} & \multicolumn{1}{c|}{$\mathbf{t}$} & $\mathbf{p}>|\mathbf{t}|$ \\
\hline Inflation rate & -0.222 & -2.49 & 0.014 \\
\hline
\end{tabular}

From the p-value presented in Table 8, we found strong evidence at the 95 percent confidence interval against the null hypothesis that inflation rate does not have a statistically significant effect on securities market returns $(p=0.014)$. Hence, the study rejected the null hypothesis, finding that inflation rate had a statistically significant effect on securities market returns.

From the regression estimates in Table 8 , it is evident that the coefficient of inflation rate was negative 0.222 . Since the study was based on a log$\log$ model, this meant that the elasticity of securities market returns with respect to inflation rate was negative 0.222 , implying that a one percentage increase in inflation rate led to a 0.222 percentage decline of securities market returns. Thus, the study found that inflation rate had a negative effect on securities market returns. This finding agrees with [62] and [17] who argued that unexpected inflation correlates to securities returns more negatively because of the perception that unexpected inflation contains new information that increases stock price volatility.

Contrary to Fisher's hypothesis, the study's findings also agreed with those of [19] - [25] outside Kenya and [32] - [34], [36] and [38] in Kenya.

In contrast, the study's findings differed with the findings of [26] - [28] outside Kenya, and [29] [31] in Kenya, who found a positive influence of inflation rate on securities market returns.

\subsubsection{Effect of Public Debt on Securities Market Returns}

Table 9 presents the results of the determination of the effect of public debt on securities market returns against the null hypothesis that public debt does not statistically significantly affect securities market 
returns at the Nairobi Securities Exchange, that is, $H_{0}: \beta_{2}=0$.

Table 9: Regression Estimates - Public Debt

\begin{tabular}{|c|c|c|c|c|}
\hline Variable & \multicolumn{1}{|c|}{$\boldsymbol{\beta}_{\mathbf{2}}$} & \multicolumn{1}{|c|}{$\mathbf{t}$} & & $\mathbf{p}>|\mathbf{t}|$ \\
\hline Public debt & -1.231 & -0.91 & 0.366 \\
\hline
\end{tabular}

From the p-value presented in Table 9, the study did not find evidence at the 95 percent confidence interval against the null hypothesis that public debt does not have a statistically significant effect on securities market returns $(p=0.366)$. Hence, the study failed to reject the null hypothesis, finding that public debt had a statistically insignificant effect on securities market returns. A study by [28] had found that public debt's effect on securities market returns was insignificant in developed European Union nations and significant in emerging European Union nations. Studies by [39] and [40] found that public debt's effect on the securities market was insignificant in both Nigeria and Kenya respectively.

From the regression estimates in Table 9, it is evident that the coefficient of public debt was negative 1.231. Since the study was based on a log$\log$ model, again this meant that the elasticity of securities market returns with respect to public debt was negative 1.231, implying that a percentage increase in public debt led to a 1.231 percentage decline of securities market returns. Thus, the study found that public debt had a negative effect on securities market returns. Although literature on the effect of public debt on securities market returns is still lean, this finding agrees with [40] in Kenya. In contrast this finding differed with the finding of [28] in the European Union, and [41] in Nigeria's securities market who found that public debt had a positive influence on stock prices.

4.4.3 Moderating Effect of Public Debt on the Effect of Inflation Rate on Securities Market Returns

Table 10 presents the results of the determination of the moderating effect of public debt on the effect of inflation rate on securities market returns against the null hypothesis that public debt does not statistically significantly moderate the effect of inflation rate on securities market returns at the Nairobi Securities Exchange, that is, $H_{0}: \emptyset_{1}=0$.

Table 10: Regression Estimates - Interaction of Inflation Rate and Public debt

\begin{tabular}{|l|c|c|c|}
\hline \multicolumn{1}{|c|}{ Variable } & $\emptyset_{\mathbf{1}}$ & $\mathbf{t}$ & $\mathbf{p}>|\mathbf{t}|$ \\
\hline Int. & -2.667 & -0.99 & 0.326 \\
\hline
\end{tabular}

Int. = interaction between inflation rate and public debt
From the p-value presented in Table 10, the study did not find strong evidence at the 95 percent confidence interval against the null hypothesis that public debt does not have a statistically significant moderating effect on the effect of inflation rate on securities market returns $(p=0.326)$. Hence, the study failed to reject the null hypothesis, finding that public debt did not have a statistically significant moderating effect on the effect of inflation rate on securities market returns.

However, comparing the estimates of the moderated regression (Table 7) with the estimates of the unmoderated main effects regression (Table 6) the R-squared slightly increased from 0.0884 to 0.0943 indicating a slight increase in the explanatory power of the regression model. The Prob $>F$ also changed from 0.0479 to 0.1058 , the coefficient of inflation rate slightly changed in magnitude from 0.222 to -0.229 , and the coefficient of public debt changed direction from negative to positive and increased in magnitude almost 4 times, implying that although the interaction between public debt and inflation rate statistically insignificantly explained securities market returns, there was some modification of the size and magnitude of public debt's and inflation rate's effects on securities market returns. The constant term also slightly increased from 3.335 to 3.345 , indicating presence of some marginal effect of public debt on the effect of inflation rate on securities market returns, resulting from their interaction in the economy.

The moderating effect was further assessed graphically by use of simple slopes via predictive margins and average marginal effects at different levels of public debt. For meaningful analysis, one standard deviation below the mean, the mean and one standard deviation above the mean were used to represent low, medium and high values of public debt and inflation rate. Table 11 presents these obtained values.

Table 21: Low, Medium and High Inflation Rate and Public Debt

\begin{tabular}{|l|c|c|c|c|}
\hline Variable & $\begin{array}{c}\text { Mean } \\
(\overline{\boldsymbol{x}})\end{array}$ & $\begin{array}{c}\text { Std. } \\
\text { Dev. } \\
(\boldsymbol{\sigma})\end{array}$ & $\begin{array}{c}\overline{\boldsymbol{x}}-\boldsymbol{\sigma} \\
(\text { Low })\end{array}$ & $\begin{array}{c}\overline{\boldsymbol{x}}+\boldsymbol{\sigma} \\
(\text { High })\end{array}$ \\
\hline $\begin{array}{l}\text { Interest } \\
\text { rate }\end{array}$ & 2.0118 & 0.50009 & 1.5117 & 2.5119 \\
\hline $\begin{array}{l}\text { Public } \\
\text { debt }\end{array}$ & -0.00016 & 0.02051 & -0.0206 & 0.0203 \\
\hline
\end{tabular}

The values in table 11 were used to generate simple slopes that reflected the predictive relationship between different levels of inflation rate and securities market returns, at different levels of 
public debt. Table 12 presents the predictive margins at 9 different combinations of the above low, medium and high values of both inflation rate and public debt.

Table 12: Predictive Margins

\begin{tabular}{|c|c|c|c|c|c|c|}
\hline \multirow{2}{*}{\multicolumn{3}{|c|}{$\begin{array}{l}\text { Adjusted predictions } \\
\text { Model VCE }\end{array}$}} & \multicolumn{4}{|c|}{ Number of obs $=121$} \\
\hline & & & \multicolumn{4}{|c|}{ : Robust } \\
\hline \multicolumn{2}{|c|}{ Expression } & \multicolumn{5}{|c|}{ : Linear prediction, predict() } \\
\hline 1._at & \multicolumn{6}{|c|}{$\begin{array}{l}: \text { LnINF }=\text { Low } \\
\text { DdtLnPD }=\text { Low }\end{array}$} \\
\hline 2._at & \multicolumn{6}{|c|}{$\begin{array}{l}: \text { LnINF }=\text { Low } \\
\text { DdtLnPD }=\text { Medium }\end{array}$} \\
\hline 3._at & \multicolumn{6}{|c|}{$\begin{array}{l}: \text { LnINF }=\text { Low } \\
\text { DdtLnPD }=\text { High }\end{array}$} \\
\hline 4._at & \multicolumn{6}{|c|}{$\begin{array}{l}: \text { LnINF }=\text { Medium } \\
\text { DdtLnPD }=\text { Low }\end{array}$} \\
\hline 5._at & \multicolumn{6}{|c|}{$\begin{array}{l}: \text { LnINF }=\text { Medium } \\
\text { DdtLnPD }=\text { Medium }\end{array}$} \\
\hline 6._at & \multicolumn{6}{|c|}{$\begin{array}{l}: \text { LnINF }=\text { Medium } \\
\text { DdtLnPD }=\text { High }\end{array}$} \\
\hline 7._at & \multicolumn{6}{|c|}{$\begin{array}{l}: \text { LnINF = High } \\
\text { DdtLnPD = Low }\end{array}$} \\
\hline 8._at & \multicolumn{6}{|c|}{$\begin{array}{l}: \text { LnINF }=\text { High } \\
\text { DdtLnPD }=\text { Medium }\end{array}$} \\
\hline 9._at & \multicolumn{6}{|c|}{$\begin{array}{l}: \text { LnINF }=\text { High } \\
\text { DdtLnPD }=\text { High }\end{array}$} \\
\hline & Margin & \begin{tabular}{|c|} 
Delta- \\
method \\
Std. \\
Err.
\end{tabular} & $\mathrm{t}$ & $\mathrm{P}>\mathrm{t}$ & $\begin{array}{l}{[95 \%} \\
\text { Conf } \\
\text { Inter }\end{array}$ & \\
\hline at & & & & & & \\
\hline 1 & 2.993 & 0.039 & 76.36 & 0.00 & 2.91 & 3.07 \\
\hline 2 & 2.999 & 0.026 & 112.09 & 0.00 & 2.94 & 3.05 \\
\hline 3 & 3.004 & 0.036 & 81.48 & 0.00 & 2.93 & 3.07 \\
\hline 4 & 2.906 & 0.034 & 84.78 & 0.00 & 2.83 & 2.97 \\
\hline 5 & 2.884 & 0.034 & 84.55 & 0.00 & 2.81 & 2.95 \\
\hline 6 & 2.863 & 0.049 & 57.89 & 0.00 & 2.76 & 2.96 \\
\hline 7 & 2.819 & 0.063 & 44.18 & 0.00 & 2.69 & 2.94 \\
\hline 8 & 2.770 & 0.076 & 36.28 & 0.00 & 2.61 & 2.92 \\
\hline 9 & 2.721 & 0.108 & 25.07 & 0.00 & 2.50 & 2.93 \\
\hline
\end{tabular}

Figure 6 presents the graphical predictive margins that simplify analysis of moderation effects using simple slopes.

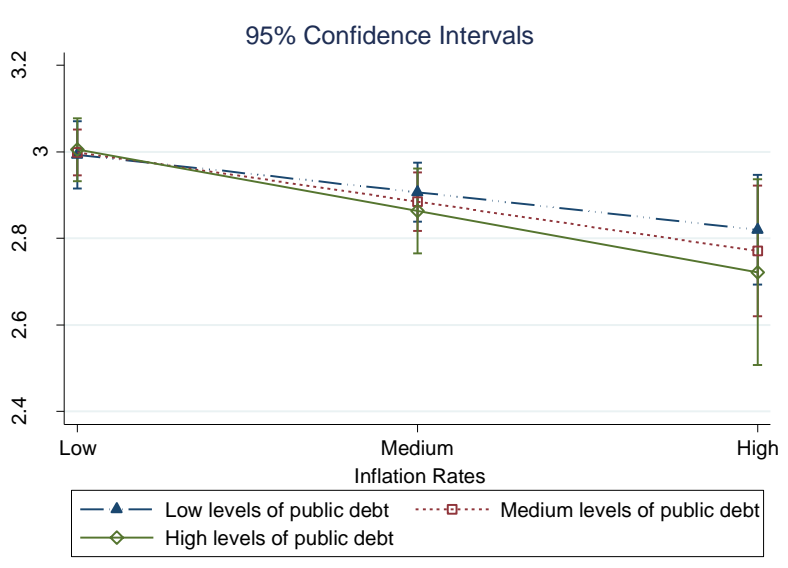

Figure 6. Inflation predictive margins at different public debt levels

It is evident from Figure 6Error! Reference source not found. that, ceteris paribus, the slope of inflation rate's linear prediction of securities market returns was more negatively pronounced at high levels of public debt. However, it became less negative as public debt declined. This implies that the elasticity of securities market returns with respect to inflation rate was decreasing (becoming less negative) with decreases in public debt. That is, at high levels of public debt in the economy, the magnitude of predicted securities market returns was higher during periods of low inflation rate than during periods of high inflation rate. In contrast, at low levels of public debt, the magnitude of securities market returns was higher during periods of high inflation rate than during periods of low inflation rates. For an even clearer picture, the simple slopes were extrapolated to include two standard deviations below the mean inflation rate, to represent very low inflation rate. Figure 7 presents the extrapolated predictive margins obtained.

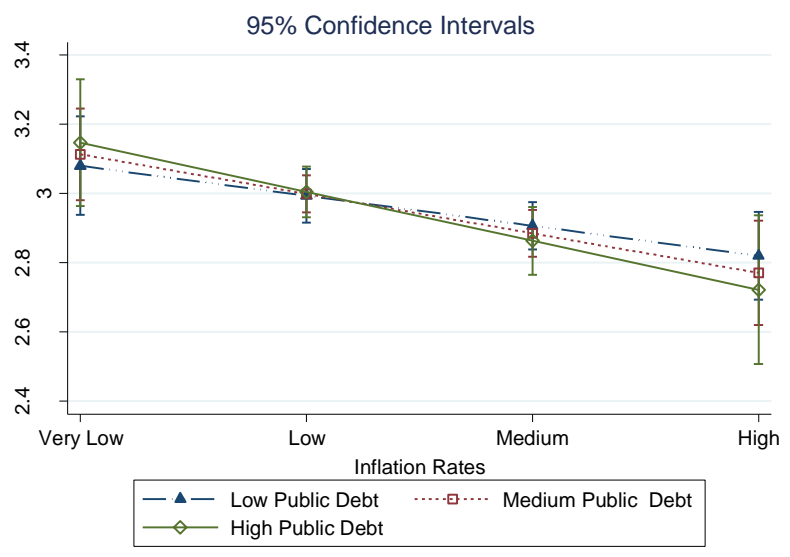

Figure 7. Inflation predictive margins including very low inflation rate

It is evident from Figure 7 that, although the confidence intervals overlap a bit, when public debt levels in the economy are high, there would be a higher probability that securities market returns 
would be higher at very low inflation rates. It can also be observed that when the prevailing interest rates are high, lower public debt levels would mean higher securities market returns. However, it is also evident from Figure 7 that high levels of public debt during periods of high inflation rate led to a decline in securities market returns.

The above predictive margins were summarized further into average marginal effects to find out the instantaneous rate of change of securities market returns with respect to inflation rate at different levels of public debt. Table 13 presents the average marginal effects of the effect of inflation rate on securities market returns at the low, medium and high values of public debt.

Table 13: Average Marginal Effects

\begin{tabular}{|c|c|c|c|c|c|}
\hline \multicolumn{2}{|c|}{$\begin{array}{l}\text { Mean Marginal } \\
\text { Effects }\end{array}$} & \multicolumn{4}{|c|}{ Number of obs $=121$} \\
\hline \multicolumn{2}{|c|}{ Model VCE } & \multicolumn{4}{|c|}{ Robust } \\
\hline \multicolumn{2}{|c|}{ Expression } & \multicolumn{4}{|c|}{ : Linear prediction, predict() } \\
\hline \multicolumn{2}{|c|}{ Dy/dx w.r.t. } & \multicolumn{4}{|c|}{ : LnINF } \\
\hline 1._at & \multicolumn{5}{|c|}{ : Low Public Debt } \\
\hline 2._at & \multicolumn{5}{|c|}{ : Medium Public Debt } \\
\hline 3._at & \multicolumn{5}{|c|}{ : High Public Debt } \\
\hline \multirow{2}{*}{$\frac{\text { LnINF }}{\text { at }}$} & \multirow[t]{2}{*}{ Margin } & \multirow[t]{2}{*}{$\mathrm{t}$} & \multirow[t]{2}{*}{$\mathrm{P}>\mathrm{t}$} & \multicolumn{2}{|c|}{$\begin{array}{c}95 \% \\
\text { Conf. } \\
\text { Interval] }\end{array}$} \\
\hline & & & & & \\
\hline 1 & -.173 & -2.15 & 0.0 & -.33 & -.013 \\
\hline 2 & -.228 & -2.48 & 0.0 & -.41 & -.046 \\
\hline 3 & -.282 & -2.20 & 0.0 & -.53 & -.028 \\
\hline
\end{tabular}

Figure 8 presents the graphical average marginal effects that simplify analysis of moderation effects using simple slopes.

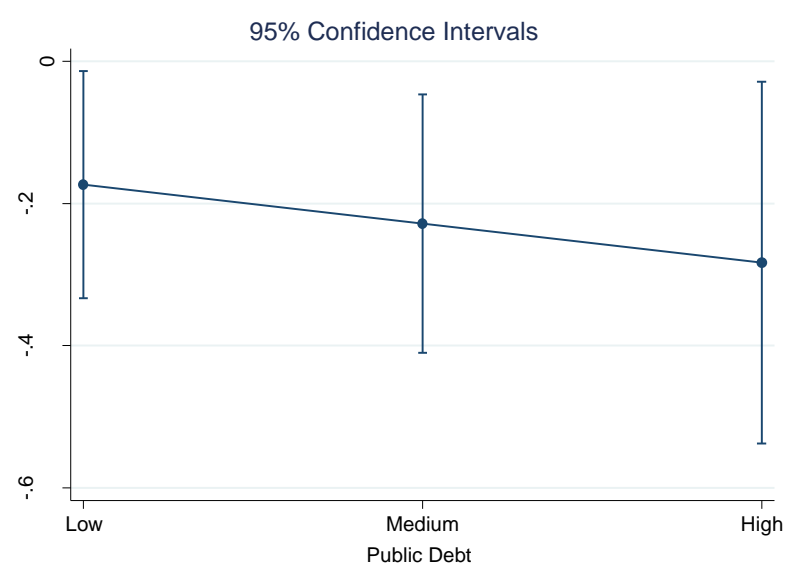

Figure 8. Average marginal effects at different public debt levels

It is evident from Figure 8 that the average marginal effects of public debt on securities market returns with respect to inflation rate were negative. This means that as public debt increased, the additional predicted securities market returns declined, that is, the rate of change of securities market returns with respect to inflation rate declined.

Because literature on the moderating effect of public debt on the effect of inflation rate on securities market returns is very limited, and since the securities market is one of the indicators of economic growth [63], the findings of this study that public debt moderates the relationship between inflation and securities market returns is in line with economic theory. According to [64], increased government expenditure and public debt increases growth of money supply, which discourages private investment with no overall decline in aggregate demand. This increases the demand-side costs of inflation due to the expectation of future increase in tax on incomes and profits to pay the debt, causing less money to be invested in the financial markets. According to [12], public debt is inflationary and inflation rate itself is crippling to the economy in the long run.

The results of this study therefore support the findings of [46], which suggest that the optimal levels of public debt should be pegged on the interaction between inflation rate and public debt in order to achieve economic growth where securities market returns increase rather than decline.

\section{Conclusion}

This study has found a strong evidence against the null hypothesis that inflation rate's effect on securities market returns was not statistically significant. It can then be concluded that inflation rate significantly influenced securities market returns in Kenya. This effect was negative, meaning that higher levels of inflation rate were bad for the Kenyan securities market.

Concerning the effect of public debt on securities market returns, we found weak evidence against the null hypothesis that public debt's effect on securities market returns was not statistically significant. It is then safe to conclude that public debt had an insignificant effect on securities market returns in the Kenyan securities market. Since this effect was negative, it implies that higher levels of public debt were bad for the securities market in Kenya, albeit insignificantly.

In terms of presence of any moderating effect of public debt on the effect of inflation rate on securities market returns, we did not find strong evidence against the null hypothesis that public debt does not statistically significantly moderate the 
effect of inflation rate on securities market returns at the Kenyan securities market. We therefore conclude that public debt had a negative, but insignificant moderating effect on the effect of inflation rate on securities market returns in Kenya. Based on the predictive margins and average marginal effects, it can be concluded that higher level of public debt is not suitable for the securities market, especially with rising prevailing inflation rates. Similarly, when the prevailing inflation rates are low, low public debt is also not desirable for the securities market. In addition, rising public debt is inflationary, thus as public debt levels in the economy rises, the rate of decline of securities market returns as a result of the adverse effects of inflation rate rises.

\subsection{Recommendations}

Based on the findings, this paper recommends that the Central Bank of Kenya's monetary policy interventions to maintain price stability in the economy should focus on the interaction between public debt and inflation rate, targeting a threshold level of inflation rate and public debt. Specifically, during periods of escalating levels of public debt, the monetary policy interventions should aim to maintain the inflation rate at low levels, preferably even lower than 4.5 percent.

Kenya's levels of public debt are high and still escalating. Therefore, measures should be put in place to stem the rising level of borrowing. Reducing public debt would help control the rise of inflationary money supply. The government should also address the issue corruption and bureaucracy with a view to reduce them so that borrowed funds are used on intended productive activities that would provide sufficient sources of funds to help pay back the debts. This will assist in cutting back on taxation and reducing the size of government in order to encourage private investment at the securities market.

In order to maximize their securities returns, investors at the Kenyan securities market should keenly monitor the interplay between inflation rate and public debt. Given that public debt levels are already high, any signs of rising inflation rates should signal such investors to shift from securities market instruments to other alternative forms of investment.

Lastly, future research could consider inclusion of a control variable in the assessment of the moderating effect of public debt on the effect of inflation rate on securities market returns since these inflation rate and public debt are not isolated in the economy. They could also consider measuring public debt as a percentage of gross domestic product in the analysis.

\section{Acknowledgements}

The authors wish to acknowledge the Nairobi Securities Exchange, Kenya National Bureau of Statistics as well as the Central Bank of Kenya, whose databases were utilized in accessing the necessary data.

\section{References}

[1] J. M. Wabwire, G. Owuor, S. Onyuma and A. Njuguna, "The effect of initial public offer announcements on market returns of listed stocks at the Nairobi stock exchange," International Journal of Research in Management, vol. 2, no. 3, pp. 84-119, 2013.

[2] C. Osoro and A. Jagongo, "Investors perceptives on the NASI and the NSE 20 share index as performance measurement indicators at the Nairobi securities exchange In Kenya," International Journal of Humanities and Social Science, vol. 3, no. 18, 2013.

[3] C. A. Yartey, Determinants of stock market development in emerging economies: Is South Africa different?, Washington: International Monetary Fund, 2008.

[4] B. S. Black and R. J. Gilson, "Does venture capital require an active stock market?," Journal of Corporate Finance, vol. Winter Edition, no. 36-48, 1999.

[5] R. L. Olson, The handbook for investment committe members: How to make prudent investment decisions for your organization, New Jersey, NJ: John Wiley \& Sons, 2005.

[6] O. Odera, L. O. Odhiambo, J. Kieran and S. B. Jaafar, "Determining the accuracy of Nairobi stock exchange-20 share index," Nairobi Kenya, 2000.

[7] H. Guo, "Stock market returns, volatility, and future output," Review-Federal Reserve Bank of Saint Louis, vol. 84, no. 5, pp. 75-84, 2002.

[8] J. N. Waithaka, "The effectiveness of the NSE 20 share index in representing the overall market performance at Nairobi security exchange," University of Nairobi, Nairobi, Kenya.

[9] CMA, Capital Markets Authority quarterly statistical bulletin, quarter ended December 2016, Nairobi, Kenya: Capital Markets Authority, 2017.

[10] CBK, "The Kenya financial sector stability 
report, 2015," Central Bank of Kenya, Nairobi Kenya, August, 2016.

[11] CBK, "Central Bank of Kenya Inflation rates [Data file]," Nairobi, 2018a.

[12] R. Lipsey and A. Chrystal, Economics, 12th ed., New York: Oxford University Press, 2011.

[13] N. V. Bon, "The relationship between public debt and inflation in developing countries: Empirical evidence based on difference panel gmm," Asian Journal of Empirical Research, vol. 5, no. 9, pp. 128-142, 2015.

[14] CBK, "Central Bank of Kenya Public debt [Data file]," Nairobi, 2018b.

[15] J. W. Kiringai and J. K. Kristensen, "Kenya economic update - beyond resilience : increasing productivity of public investments," World Bank Group, Washington, D.C, 2016.

[16] A. Uwubanmwen and I. L. Eghosa, "Inflation rate and stock returns: Evidence from the Nigerian stock market," International Journal of Business and Social Science, vol. 6, no. 11, pp. 155-167, 2015.

[17] A. Cifter, "Stock returns, inflation, and real activity in developing countries: A Markovswitching approach," Panoeconomicus, vol. 62, no. 1, pp. 55-76, 2015.

[18] I. Fisher, The theory of interest, New York: MacMillan, 1930.

[19] Y. Hsing, "The stock market and macroeconomic variables in a BRICS country and policy implications," International Journal of Economics and Financial Issues, vol. 1, no. 1, pp. 12-18, 2011.

[20] M. B. Ali, "Impact of micro and macroeconomic variables on emerging stock market return: A case on Dhaka stock exchange (DSE)." 1.5 (2011): 8-16.," Interdisciplinary Journal of Research in Business, vol. 1, no. 5, pp. 8-16, 2011.

[21] J. T. Talla, "Impact of macroeconomic variables on the stock market prices of the Stockholm stock exchange (OMXS30)," Jonkoping International Business School, Stockholm, 2013.

[22] O. A. Usman and A. T. Adejare, "Inflation and capital market performance: The Nigerian outlook," Journal of Emerging Trends in Economics and Management Sciences, vol. 5, no. 1, pp. 93-99, 2013.

[23] K. J. Bolokwe and I. Radikoko, "Investigating the impact of inflation on the returns of Botswana's equity market," Journal of
Accounting and Finance, vol. 17, no. 9, pp. 3145, 2017.

[24] G. Innocent, J. Shukla, P. Mulyungi and A. Ochieng, "Effects of macroeconomic variables on stock market performance in rwanda. Case study of Rwanda Stock Exchange," European Journal of Economic and Financial Research, vol. 3, no. 1, pp. 104-125, 2018.

[25] C. R. S. Chaves and A. C. Silva, "Inflation and stock returns at B3," SSRN Papers, pp. 1-22, 2018 .

[26] J. K. M. Kuwornu and V. Owusu-Nantwi, "Macroeconomic variables and stock market returns: Full information maximum likelihood estimation," Research Journal of Finance and Accounting, vol. 2, no. 4, pp. 49-63, 2011.

[27] S. M. Hosseini, Z. Ahmad and Y. W. Lai, "The role of macroeconomic variables on stock market index in China and India," International Journal of Economics and Finance, vol. 3, no. 6, p. 233, 2011.

[28] T. Barbić and I. Ćondić-Jurkić, "Do fiscal variables affect stock market returns in EU Countries?," Ekonomski pregled, vol. 68, no. 3, pp. 253-266, 2017.

[29] T. Olweny and K. Omondi, "The effect of macro-economic factors on stock return volatility in the Nairobi stock exchange, Kenya," Economics and Finance Review, vol. 1, no. 10, pp. 34-48, 2011.

[30] N. N. Waweru, "Analysis of the determinants of stock price volatility at Nairobi securities exchange," University of Nairobi, 2013.

[31] D. A. Otieno, R. W. Ngugi and P. W. Muriu, "The impact of inflation rate on stock market returns: Evidence from Kenya," Journal of Economics and Finance, pp. 1-18, 2018.

[32] S. O. Onyuma, "Analysis of the financial deepening determinants influencing securities market development in Kenya," Unpublished $\mathrm{PhD}$ thesis, 2017.

[33] R. K. Songole, "The relationship between selected macroeconomic variables and stock return at the Nairobi Securities Exchange," University of Nairobi, Nairobi, Kenya, 2012.

[34] D. K. Kimani and C. M. Mutuku, "Inflation dynamics on the overall stock market performance: The case of Nairobi Securities Exchange in Kenya," Economics and Finance Review, vol. 2, no. 11, pp. 1-11, 2013.

[35] D. O. Mogoi, "The effect of inflation on stock returns and volatility at the Nairobi securities 
exchange," University of Nairobi, Nairobi, Kenya, 2014.

[36] K. Muriuki, "The effect of inflation and interest rates on stock market returns of firms listed at the Nairobi securities exchange," University of Nairobi, Nairobi, Kenya, 2014.

[37] S. Mainga, "Effect of macro-economic factors on stock returns at the Nairobi Stock Exchange," United States International University-Africa, Nairobi, Kenya, 2014.

[38] C. Mutuku and K. L. Ng'eny, "Macroeconomic variables and the Kenyan equity market: A time series analysis," Business and Economic Research, vol. 5, no. 1, pp. 1-10, 2015.

[39] O. S. Aigheyisi and J. O. Edore, "Do government expenditure and debt affect stock market development in nigeria? An empirical investigation," Research Journal of Finance and Accounting, vol. 5, no. 20, pp. 1-11, 2014.

[40] F. K. Meme and W. Muturi, "The relationship between government domestic debt and stock," International Journal of Social Sciences and Information Technology, vol. Vol II, no. Issue IX, pp. 1035-1051, 2016.

[41] O. M. Ogbulu, L. L. Torbira and C. L. Umezinwa, "Assessment of the impact of fiscal policy operations on stock price performance: Empirical evidence from Nigeria," International Journal of Financial Research, vol. 6, no. 2, pp. 190-202, 2015.

[42] CBK, "Central Bank of Kenya Monetary policy," 2018c. [Online]. Available: https://www.centralbank.go.ke/monetarypolicy/.

[43] S. Bhattarai, J. W. Lee and W. Y. Park, "Inflation dynamics: The role of public debt and policy regimes," Journal of Monetary Economics, vol. 67, no. C, pp. 93-108, 2014.

[44] S. Fischer, R. Sahay and C. A. Végh, "Modern hyper- and high inflations," Journal of Economic Literature, vol. 40, no. 3, p. 837880, 2002.

[45] J. A. Lopes da Veiga, A. Ferreira-Lopes and T. N. Sequeira, "Public debt, economic growth, and inflation in African economies," South African Journal of Economics, vol. 84, no. 2, pp. 294-322, 2016.

[46] S. G. Cecchetti, M. S. Mohanty and F. Zampolli, "The real effects of debt," in No. 352, BIS Working Papers, 2011.

[47] D. N. Gujarati and D. C. Porter, Basic econometrics, 5th ed., New York, NY:
McGraw-Hill/Irwin, 2009.

[48] A. D. Ho and C. C. Yu, "Descriptive statistics for modern test score distributions: Skewness, kurtosis, discreteness, and ceiling effects," Educational and Psychological Measurement, vol. 75, no. 3, pp. 365-388, 2014.

[49] C. Brooks, Introductory Econometrics for Finance, New York: Cambridge University Press, 2008, p. 8.

[50] K. Patterson, An introduction to applied econometrics: A time series approach, Houndmills, UK: Macmillan Press Limited, 2000.

[51] J. W. Osborne, "The effects of minimum values on data transformations," Education Research Information Center: Paper presented at the Annual Meeting of the American Educational Research Association (New Orleans, LA, April 1-5, 2002), New Orleans, LA, 2002.

[52] C. W. J. Granger and P. Newbold, "Spurious Regressions in Econometrics," Journal of Econometrics, vol. 2, pp. 111-120. , 1974.

[53] J. M. Wooldridge, Introductory econometrics: A modern approach, 5th ed., South-Western: Cengage Learning, 2013.

[54] R. J. Hyndman and G. Athanasopoulos , Forecasting: principles and practice, Online: OTexts, 2013.

[55] D. Gujarati, Econometrics by example, Houndmills, Basingstoke, Hampshire: Palgrave Macmillan, 2012.

[56] R. C. Hill, W. E. Griffiths and G. C. Lim, Principles of econometrics, 4th ed., New York, United States: John Wiley \& Sons Ltd, 2016.

[57] A. C. Cameron and P. K. Trivedi, Microeconometrics using stata, Revised ed., College Station, Texas: Stata Press, 2010.

[58] J. Cohen, Statistical power analysis for the behavioral sciences, 2nd ed., Hillsdale, NJ: Erlbaum, 1988.

[59] A. J. Fairchild and S. D. McQuillin, "Evaluating mediation and moderation effects in school psychology: a presentation of methods and review of current practice," Journal of school psychology, vol. 48, no. 1, pp. 53-84, 2010.

[60] H. S. Wu, "How to model mediating and moderating effects," in Workshop Series, 2011.

[61] A. F. Hayes, Mediation, moderation, and conditional process analysis: A regression based-approach, Second ed., New York, NY: The Guilford Press, 2013. 
[62] C. Wei, "Does the stock market react to unexpected inflation differently across the business cycle?," Applied Financial Economics, vol. 19, no. 24, pp. 1947-1959, 2009.

[63] N. M. Masoud, "The impact of stock market performance upon economic growth," International Journal of Economics and Financial Issues, vol. 3, no. 4, pp. 788-798, 2013.

[64] J. Sloman and D. Garratt, Essentials of economics, Fifth ed., Harlow, England: financial Times Prentice Hall, 2010.

[65] J. O. Rawlings, S. G. Pantula and D. A. Dickey, Applied regression analysis: a research tool, New York, NY: Springer Science \& Business Media, 2001.

[66] T. Ryan and I. Maana, "An assessment of Kenya's public debt dynamics and sustainability," Central Bank of Kenya, Nairobi, 2014.

[67] A. Jagongo and V. S. Mutswenje, "A Survey of the factors influencing investment decisions: The case of individual investors at the NSE," International Journal of Humanities and Social
Science, vol. 4, no. 4 (The Special Issue on Contemporary Issues in Social Science), pp. 92102, 2014.

[68] W. N. Ngugi, "Effect of public debt on economic growth in Kenya," Unpublished Master of Science in Finance Dissertation, Nairobi, 2016.

[69] W. Wu, Information asymmetry and insider trading, 2014, pp. 13-67.

[70] M. M. Yassin, H. Y. Ali and M. E. Hamdallah, "The relationship between information asymmetry and stock return in the presence of accounting conservatism," International Journal of Business and Management, vol. 10, no. 5, pp. 126-133, 2015. 